\title{
Modeling trophic structure and energy flows in a shallow lake, Yangtze River Basin, China: a case analysis for culture-based fishery practices
}

\author{
Chang Li ${ }^{1,2}$, Qidong Wang ${ }^{1}$, Shaowen Ye ${ }^{1}$, Geng Huang ${ }^{1,2}$, Jiashou Liu ${ }^{1}$, \\ Zhongjie Li ${ }^{1, *}$
}

${ }^{1}$ State Key Laboratory of Freshwater Ecology and Biotechnology, Institute of Hydrobiology, Chinese Academy of Sciences, Wuhan 430072, PR China

${ }^{2}$ University of Chinese Academy of Sciences, Beijing 100049, PR China

\begin{abstract}
Culture-based fisheries (CBFs) in China are well developed in most lakes; however, an ecological approach is required to assess and improve them. This study aimed to describe the characteristics of the aquatic ecosystem of Lake Shangshe (Yangtze River Basin, China) and propose suggestions to improve CBF practices using an Ecopath with Ecosim model. Based on the direction of water flow and different product supply services, different practices were implemented in the 3 sub-lakes of Lake Shangshe (upper lake area, ULA; middle lake area, MLA; lower lake area, LLA) between 2014 and 2015. Asian carp (Hypophthalmichthys molitrix, H. nobilis, Ctenopharyngodon idella, Cyprinus carpio) and bream (Megalobrama amblycephala, Parabramis pekinensis) were stocked at 30.0 and $50.0 \mathrm{t} \mathrm{km}^{-2}$ in the ULA and MLA, respectively. In the LLA, the same fish species were stocked at $50.0 \mathrm{t} \mathrm{km}^{-2}$ and millet grass Echinochloa sp. was planted. Water quality, including physicochemical parameters, was monitored in the 3 sub-lakes. Total phosphorus and chemical oxygen demand were significantly lower in the ULA than in the MLA and LLA. Ecotrophic efficiency values were noticeably high for most of the functional groups, except small pelagic fishes and cyanobacteria. Mixed trophic impact analyses demonstrated high fishing pressure on piscivorous fishes. The total mean transfer efficiency (TE) was $14.4 \%$. The ratios of total primary production to total respiration, total primary production to total biomass, and total biomass to total throughput were $1.847,46.131$, and 0.008 , respectively. In conclusion, the TE and ecosystem maturity of the aquatic ecosystem of Lake Shangshe were higher than those of other lakes in China, with the trialed CBF practices having a positive effect on both factors.
\end{abstract}

KEY WORDS: Culture-based fisheries - Trophic structure - Transfer efficiency - Ecopath with Ecosim $\cdot$ Lake Shangshe $\cdot$ Yangtze River Basin

\section{INTRODUCTION}

Aquaculture is a millennia-old tradition that is thought to have originated in China over 2500 yr ago, contributing to the success in global food security and the social economy (Wu et al. 1992). China is the largest inland fishery producer in the world, with a total production of $32.98 \mathrm{Mt}$ in 2015, corresponding to $54.7 \%$ of global inland fishery production $(60.32 \mathrm{Mt})$, including capture and aquaculture production (FAO 2017). Culture-based fisheries (CBFs) are a mode of

${ }^{*}$ Corresponding author: zhongjie@ihb.ac.cn fisheries enhancement that is practiced in most lakes and reservoirs in China and recognized as a significant contributor to inland fish production ( $\mathrm{Li} \& \mathrm{Xu}$ 1995, De Silva 2003, Wang et al. 2015). CBF practices exhibit broad diversity with respect to the type of water bodies utilized, species stocked, harvesting techniques, and management strategies (De Silva 2003). Various CBF practices are implemented in China, including those involving the modification of water bodies to stock silver carp Hypophthalmichthys molitrix and bighead carp H. nobilis, the trans-

(C) The authors 2018. Open Access under Creative Commons by Attribution Licence. Use, distribution and reproduction are unrestricted. Authors and original publication must be credited. 
plantation of macrophytes to culture grass carp Ctenopharyngodon idella and Chinese mitten crab Eriocheir sinensis, and the elimination of fish species with low economic value ( $\mathrm{Li} \& \mathrm{Xu}$ 1995, De Silva 2003, Wang et al. 2015).

Modification of water bodies, cutting off small and controllable water areas from the main body by embankments, weirs, or nets to serve for extensive and intensive fishery practices, is widely implemented for stock enhancement in CBFs. These improvisations in a water body result in minimal loss of stocked seed, facilitate complete harvesting, and incur low cost in small water bodies (Li \& Xu 1995, Welcomme \& Bartley 1998, Ingram \& De Silva 2015). During the 1980s and 1990s, semi-intensive and intensive aquaculture methods, including the use of pen and purse net cultures, were applied to lake fisheries in China. These practices substantially increased fishery production and incomes of fishers (Zeng 1995, Lian et al. 2016). However, these CBF practices in lakes have also generated a range of environmental problems, such as habitat fragmentation (Yang et al. 2010), deterioration of water quality, and eutrophication (Zhang \& Mei 1996, Wang et al. 2009, Rico et al. 2012). Conflict between developing CBFs and protecting the environment has drawn the attention of stakeholders. Currently, the management strategies of lake fisheries in China are being gradually diverted from seeking high production exclusively to including water quality protection.

Macrophytes play a prominent role in primary production, water quality improvement (Jeppesen et al. 1998, Dhote \& Dixit 2009), nutrient cycling (Carpenter et al. 1998), and phytoplankton biomass reduction (Søndergaard \& Moss 1998). To reconcile fish production with environmental protection, it is necessary to transplant and/or recover macrophytes in lakes. Macrophytes have a high capacity for absorbing and storing nutrients from water and sediment (Boyd 1970, Dhote \& Dixit 2009), resulting in their having substantial nutrient status (Mandal et al. 2010). Thus, the direct use of macrophytes as food or their indirect use when blended with feedstuffs as feed for herbivorous fishes could replace costly commercial feeds (Mandal et al. 2010), in parallel to extracting nitrogen and phosphorus from water, which will contribute towards environmental integrity (Barko \& James 1998). Millet grass Echinochloa sp. was imported to China from Australia in 1983 and is an emergent macrophyte that can be transplanted to feed herbivorous and filter-feeding fishes (Gong et al. 1992, Li \& Xu 1995). Previous studies have demonstrated that the transplantation of millet grass to cultivate grass carp $C$. idella, silver carp $H$. molitrix, and bighead carp $H$. nobilis reduces feed and manure costs, increases the flesh quality of fishes, and decreases production costs (Li \& Xu 1995, Cheng et al. 2015, 2016).

Undoubtedly, CBF in China has contributed significantly towards increasing fish production, and emphasis is now being laid on enhancing environmental and ecological factors in these practices. A holistic ecological understanding is fundamental for optimizing the management of natural resources and maintaining the health of ecosystems (Chea et al. 2016). Trophic structure and interactions play a decisive role in determining the dynamics of an ecosystem and are of interest in many studies aimed at improving fisheries management (Kitchell et al. 2000, Guo et al. 2013, Zhou et al. 2015). In this regard, an ecological approach to assess and improve CBF practices in lakes is urgently required.

The Ecopath with Ecosim (EwE) model has a standard modeling procedure and a user-friendly interface and has thus become a commonly used software package for documenting and analyzing trophic structure and energy flows (Christensen et al. 2005). This model is based on the theories of Odum (1969), Finn (1976), and Ulanowicz (1986), facilitating comparisons among different ecosystems with respect to trophic structure, energy flows, and ecosystem properties. The EwE model was introduced to China by Tong (1999) and has since been used on many aquatic ecosystems, especially ocean systems (Tong et al. 2000, Chen et al. 2006). Today, the EwE model has been applied for many lakes in China, including Lakes Qiandao (Liu et al. 2007, 2010), Taihu (Li et al. 2009, 2010, 2014), Bao'an (Guo et al. 2013), Chaohu (Liu et al. 2014, Kong et al. 2016), and Dianchi (Shan et al. 2014).

In the present study, the EwE model was developed for a shallow lake (Lake Shangshe) managed under CBFs to describe the characteristics of trophic structure, energy flows, and ecosystem properties. This information was used to develop suggestions to improve CBF practices.

\section{MATERIALS AND METHODS}

\section{Study site}

Lake Shangshe $\left(30^{\circ} 07^{\prime}-30^{\circ} 09^{\prime} \mathrm{N}, 114^{\circ} 12^{\prime}-114^{\circ}\right.$ $18^{\prime} \mathrm{E}_{\text {; Fig. }}$ ) is a shallow lake (total area: $8.55 \mathrm{~km}^{2}$; average water depth: $2.10 \mathrm{~m}$ ) located on the Yangtze River Basin within Hubei province, central China. This lake has been separated into 3 sub-lakes by nets (Fig. 1). The lake is dominated by a northern subtrop- 


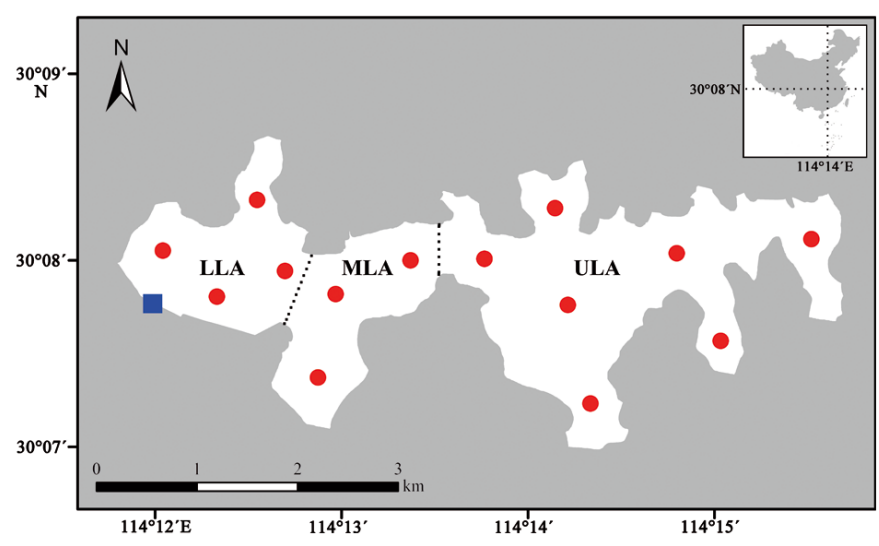

Fig. 1. Lake Shangshe, China. Red circles, blue square, and dotted lines represent sampling sites, sluice, and nets, respectively. LLA: lower lake area; MLA: middle lake area; ULA: upper lake area

ical monsoon climate. It has an annual mean air temperature of $16.20^{\circ} \mathrm{C}$ and an annual mean precipitation of $1250 \mathrm{~mm}$ (Wang \& Dou 1998).

\section{CBF practices and water quality assessment}

Fish production and drinking water supply are the main ecosystem services of Lake Shangshe. Fish stocking and harvesting are done once a year within a narrow time span in winter. The culture-cycle is one year. To facilitate the harvesting of fish, the water level is regularly controlled by a sluice. From March to November, the sluice is shut and the water level rises following each rainfall event. In January, before the harvesting season, the sluice is opened and water flows from the upper lake area (ULA), through the middle lake area (MLA) to the lower lake area (LLA), and finally into the Yangtze River. CBF practices (Table 1) were implemented concurrently in the 3 sub-lakes of Lake Shangshe between 2014 and 2015, based on the direction of the water flow and different supply services. Drinking water supply is the principal ecosystem service in the ULA; thus, fish (including silver carp Hypophthalmichthys molitrix, bighead carp $H$. nobilis, grass carp Ctenopharyngodon idella, common carp Cyprinus carpio and bream ([Megalobrama amblycephala, Parabramis pekinensis]) were stocked at low density (30.0 t $\mathrm{km}^{-2}$ ) in this lake area. Fish production is the main ecosystem service in the MLA and LLA. To make full use of nutrient flow from the ULA and to enhance fisheries yield, the above-mentioned fish species were stocked at high density $\left(50.0 \mathrm{t} \mathrm{km}^{-2}\right)$ in the MLA. To utilize nutrients in the sediment and discharged effluent that flows from the ULA and MLA, the same species were stocked at high density (50.0 t $\mathrm{km}^{-2}$ ) and millet grass Echinochloa sp. was planted in the LLA.

Water quality was monitored simultaneously at 14 sites during this study (Fig. 1). Water temperature, water depth, transparency, $\mathrm{pH}$, conductivity, and dissolved oxygen were measured in situ using a YSI Professional Plus multimeter and Secchi disk. Water was sampled from $0.5 \mathrm{~m}$ below the water surface and $0.5 \mathrm{~m}$ above the sediment, with the samples being combined and collected for laboratory chemical analysis. Samples were kept at $4^{\circ} \mathrm{C}$ until analysis. Hydrochemical variables, including total nitrogen, total phosphorus, ammonium nitrogen, and chemical oxygen demand (permanganate index) $\left(\mathrm{COD}_{\mathrm{Mn}}\right)$, were analyzed according to standard methods (APHA 1992, Huang 1999). Data were processed and statistically analyzed using SPSS (v. 22.0) and R (v. 3.3.3). Because the data sets were not independent and were abnormally distributed, the water quality of the 3 sub-lakes was analyzed using a non-parametric test (Kruskal-Wallis $H$-test). A non-parametric multiple comparison test was then performed using $\mathrm{R}$ when the results were significant. The significance of all statistical tests was set at $\alpha=0.05$.

Table 1. Fish stocking density and net yield in the 3 sub-lakes of Lake Shangshe. ULA: upper lake area; MLA: middle lake area; LLA: lower lake area

\begin{tabular}{|c|c|c|c|c|c|c|c|}
\hline \multirow[t]{2}{*}{ Fish species } & & \multicolumn{3}{|c|}{ Stocking density ( $\mathrm{t} \mathrm{km}^{-2}$ ) } & \multicolumn{3}{|c|}{ Net yield $\left(\mathrm{t} \mathrm{km}^{-2} \mathrm{yr}^{-1}\right)$} \\
\hline & & ULA & MLA & LLA & ULA & MLA & LLA \\
\hline Silver carp & Hypophthalmichthys molitrix & 4.23 & 16.25 & 14.56 & 3.94 & 14.58 & 16.99 \\
\hline Bighead carp & Hypophthalmichthys nobilis & 19.99 & 28.87 & 22.57 & 5.37 & 6.43 & 23.55 \\
\hline Grass carp & Ctenopharyngodon idella & 3.98 & 4.06 & 5.34 & -0.48 & 6.13 & 9.22 \\
\hline Common carp & Cyprinus carpio & 1.32 & 0.63 & 4.85 & 1.68 & 6.60 & 14.56 \\
\hline Bream & Megalobrama amblycephala, Parabramis pekinensis & 0.48 & 0.19 & 2.67 & -0.18 & 3.25 & 4.61 \\
\hline Total & & 30.00 & 50.00 & 50.00 & 10.32 & 36.99 & 68.94 \\
\hline
\end{tabular}




\section{Modeling approach}

A static mass-balance model for Lake Shangshe was constructed by using EwE (v. 6.2). To express mass balance, the model includes a set of linear equations. The basic mass-balance equation of EwE is formulated as follows:

$B_{i} \times(P / B)_{i} \times \mathrm{EE}_{i}-\sum_{j=1}^{n} B_{j} \times(Q / B)_{j} \times \mathrm{DC}_{j i}-\mathrm{EX}_{i}=0$

where $B_{i}(P / B)_{i}$, and $\mathrm{EE}_{i}$ represent the biomass, production/biomass ratio, and ecotrophic efficiency of group $i$, respectively; $B_{j}$ and $(Q / B)_{j}$ are the biomass and the consumption/biomass ratio of predator $j$, respectively; $\mathrm{DC}_{i j}$ represents the contribution of prey $i$ in the diet of predator $j_{i}$ and $\mathrm{EX}_{i}$ is the export of group $i$ (Allen 1971, Christensen \& Walters 2004, Christensen et al. 2005). To balance models, $\mathrm{DC}_{i j}$ and at least 3 of $B, P / B, Q / B$, and EE should be input. The rest of the unknown parameters can be calculated by Ecopath models.

\section{Data collection and parameter estimation}

Based on the research objectives, availability of information, trophic habits, and abundance, 21 functional groups were defined to construct a massbalance model for Lake Shangshe. Some commercial fish species were grouped separately due to their importance to fisheries yield and stocking. Overstocking of grass carp has resulted in the total elimination of submerged macrophytes in the 3 sub-lakes.
Therefore, submerged macrophytes were not considered in the model. Table 2 shows a list of functional groups in the lake ecosystem.

The biomass of the fish group was estimated using the following 3 equations:

$$
\begin{aligned}
& B=Y / F \\
& F=Z-M \\
& Z=P / B=K \times\left(L_{\infty}-\bar{L}\right) /\left(\bar{L}-L^{\prime}\right)
\end{aligned}
$$

where $B$ is the biomass $\left(\mathrm{t} \mathrm{km}^{-2}\right), Y$ is the annual catch yield $\left(\mathrm{t} \mathrm{km}^{-2} \mathrm{yr}^{-1}\right), F$ is the fishing mortality $\left(\mathrm{yr}^{-1}\right), Z$ is the total mortality $\left(\mathrm{yr}^{-1}\right)$, and $M$ is the natural mortality $\left(\mathrm{yr}^{-1}\right) . K, L_{\infty}, \bar{L}$, and $L^{\prime}$ represent the growth rate of von Bertalanffy growth function, asymptotic length $(\mathrm{cm})$, mean length $(\mathrm{cm})$, and maximum length of fish (cm), respectively (Beverton \& Holt 1957, Allen 1971). $K, L_{\infty}, \bar{L}$, and $L^{\prime}$ were derived from a fish resource assessment and previously published studies. The fish resource assessment was performed with multi-mesh gillnets, with sampling every 3 mo to identify the composition of fish resources and determine the distribution of individual fish body length and weight. To calculate $Z$, the method of Beverton \& Holt (1957) was used along with FiSAT software. Harvesting in Lake Shangshe was accomplished through a combination of unified fishing methods and fyke nets within a narrow time span in winter. The net yield $\left(\mathrm{t} \mathrm{km}^{-2}\right)$, total fisheries yield $\left(\mathrm{t} \mathrm{km}{ }^{-2}\right)$, and composition (\%) of the 3 sub-lakes and the whole lake between 2014 and 2015 were obtained from the Fisheries Management Department of Lake Shangshe and are shown in Table 1 and

Table 2. Functional groups and dominant species composition of Lake Shangshe in the model

\begin{tabular}{|lll|}
\hline No. & Functional group & Dominant species \\
\hline 1 & Mandarin fish & Siniperca chuatsi, S. knerii \\
2 & Snakehead fish & Channa argus \\
3 & Topmouth culter & Culter alburnus \\
4 & Other culters & Culter dabryi, C. mongolicus, Cultrichthys erythropterus \\
5 & Common carp & Cyprinus carpio \\
6 & Crucian carp & Toxabrius auratus \\
7 & Small pelagic fishes & Pseudorasbora parva, Acheilognathus macropterus, Abbottina rivularis \\
8 & Small demersal fishes & Hypophthalmichthys molitrix \\
9 & Silver carp & H. nobilis \\
10 & Bighead carp & Ctenopharyngodon idella \\
11 & Grass carp & Megalobrama amblycephala, Parabramis pekinensis \\
12 & Bream & Macrobrachium nipponense, Procambarus clarkii \\
13 & Shrimp & Propsilocerus akamusi, Limnodrilus hoffmeisteri \\
14 & Zoobenthos & Keratella cochlearis, Trichocerca elongata \\
15 & Microzooplankton & Diaphanosoma leuchtenbergianum, Bosmina longirostris, Moina micrura \\
16 & Cladocera & Microcyclops varicans, Thermocyclops kawanurai \\
17 & Copepoda & Pseudanabaena sp., Microcystis sp., Merismopedia sp., Lyngbya sp. \\
18 & Cyanobacteria & Synedra sp., Scenedesmus quadricauda, Cryptomonas rosa, Tetraedron minimum \\
19 & Other phytoplankton & Echinochloa sp. \\
20 & Millet grass & Bioseston, abioseston, cereal \\
21 & Detritus &
\end{tabular}


Fig. S1 in the Supplement at www.int-res.com/ articles/suppl/q010p213_supp.pdf.

Natural mortality was estimated by Pauly's (1980) empirical equation:

$$
\begin{aligned}
\log M= & -0.0066-0.279 \times \log L_{\infty} \\
& +0.6543 \times \log K+0.4634 \times \log T
\end{aligned}
$$

where $T$ is the mean annual water temperature $\left({ }^{\circ} \mathrm{C}\right)$.

According to Palomares \& Pauly (1998), Q/B of fish was calculated by the following empirical equation:

$$
\begin{aligned}
\log (Q / B) & =7.964-0.204 \times \log W_{\infty}-1.965 \times T^{\prime} \\
& +0.083 \times A+0.532 \times h+0.398 \times d
\end{aligned}
$$

where $W_{\infty}$ is the asymptotic weight $(\mathrm{g}), T^{\prime}$ is the mean temperature of the lake defined as $T^{\prime}=1000 /(T+$ 273.15), $A$ is the aspect ratio for a given fish, $h$ is a dummy variable that expresses food type ( 0 for detritivores and carnivores, 1 for herbivores), and $d$ is also a dummy variable expressing food type ( 0 for herbivores and carnivores, 1 for detritivores). The morphometric data and food type were derived from Zhang (2005). The biomass of shrimp was estimated from the field survey conducted by the Fisheries Management Department of Lake Shangshe. Because of the similarity in fisheries management practices and geographical conditions between Lake Shangshe and Lake Wuhu, the $P / B$ and $Q / B$ values of Lake Shangshe were defined as 2.50 and 12.50, respectively, derived from Lin (2012).

The zoobenthos community was composed of chironomids and oligochaetes. They were sampled every 3 mo between 2014 and 2015 for the 14 stations (Fig. 1) by using a Peterson's grab sampler (Huang 1999). Because of the similarity in the composition of dominant species and geographical conditions between Lake Shangshe and Lake Taihu, $P / B$ and $Q / B$ were considered as 15.00 and 300.00, respectively, derived from Li et al. (2014).

Three major functional groups of zooplankton were considered in this model, namely microzooplankton (protozoa, rotifers), Cladocera, and Copepoda. Zooplankton was sampled monthly between 2014 and 2015 at the 14 sampling stations (Fig. 1). After microscopic identification and counting, zooplankton biomass was estimated based on the length-weight relationship (Huang 1999). In general, for the 3 major functional groups of zooplankton, 0.05 was adopted for the production/consumption ratio $(P / Q)$. For the EE values of microzooplankton, Cladocera, and Copepoda, 0.95, 0.90, and 0.90, respectively, were adopted (Park et al. 1974, Scavia et al. 1974).

The biomass of phytoplankton was measured/calculated between 2014 and 2015 each month at the 14 sampling stations (Fig. 1). Phytoplankton abundance was estimated by counting individuals, and their cell sizes were estimated to derive volumes by using a microscope. Biomass (wet weight) was calculated from abundance, cells, and wet weight density $\left(1 \mathrm{~g} \mathrm{~cm}^{-3}\right)$. Gross primary production (GPP) was estimated using the vertically generalized production model (Zeng et al. 2011). Because of the similar geographical conditions and fishery practices between Lake Shangshe and Lake Chaohu, $P / B$ of cyanobacteria was considered as 150.00, derived from Kong et al. (2016). The $P / B$ ratio for other phytoplankton was calculated as 219.44.

Detritus consists of soluble and particulate organic compounds, bacteria, and decaying matter. The total biomass of dissolved and particulate organic carbon was estimated using the empirical formula as follows (Heymans et al. 2004):

$$
\log D=0.954 \times \log \mathrm{PP}+0.863 \times \log E-2.41
$$

where $D$ is the total biomass of dissolved and particulate organic carbon $\left(\mathrm{g} \mathrm{C} \mathrm{m}^{-2}\right)$, PP represents primary production $\left(\mathrm{g} \mathrm{C} \mathrm{m}^{-2} \mathrm{yr}^{-1}\right)$, and $E$ is the euphotic depth in meters (m). Bird \& Kalff's (1984) formula was applied to calculate the bacterial biomass. This model considers the relationship between Chla and the abundance of bacteria as follows:

$$
\log \mathrm{AODC}=5.867+0.776 \times \log \mathrm{Chl} a
$$

where AODC (acridine orange direct count) is the number of bacteria per millilitre (cells ml-1) and Chla is the average concentration of $\mathrm{chl} a$ in lake water $(\mu \mathrm{g}$ $\mathrm{l}^{-1}$ ). With the volume of bacteria estimated to be $0.5 \times$ $10^{-3} \mathrm{ml}$ (Cho \& Azam 1990, Shan et al. 2014), the biomass of bacteria was calculated. Cereal, which is used to feed fishes, is a type of decaying organic matter; thus, it was considered as part of the detritus.

In this study, millet grass was planted in part of the LLA (17.3\% of the LLA, $\left.0.36 \mathrm{~km}^{2}\right)$. Millet grass was considered as a second detritus group because it was not a living consumer group when it was flooded. Its biomass was estimated from the fishery sampling survey. The diet composition (consisting of fish, shrimp, zoobenthos, microzooplankton, Cladocera, and Copepoda) was synthesized from stomach content analysis and previous studies (Zhang 2005, Ye 2007, Lin 2012, Kong et al. 2016). The dietary composition of some groups was modified with slight adjustments to balance the model, if necessary (Table $\mathrm{S} 2$ in the Supplement).

\section{Model balancing and uncertainty}

By assigning the confidence intervals based on origins, the pedigree index was used to describe the 
quality of input data and evaluate the certainty of the model. Based on the individual pedigree index values, an overall pedigree index was estimated as follows:

$$
P=\sum_{i=1}^{n} \sum_{j=1} 1_{i j} / n
$$

where $l_{i j}$ is the pedigree index for group $i$ and parameter $j$, and $n$ is the total number of groups (Christensen \& Walters 2004). In addition to the pedigree index, a measure of fit $\left(t^{*}\right)$ was also used to scale the model uncertainty that described how well a given model is rooted in local data. The formula used was as follows:

$$
t^{*}=P \times \sqrt{n-2} / \sqrt{1-P^{2}}
$$

\section{Ecosystem maturity}

The ecosystem maturity of Lake Shangshe was quantitatively assessed by using the attributes given by the EwE model. Based on the ecosystem theories implemented by Odum (1969), Odum \& Barrett (1971), and Ulanowicz (1986), a set of indicators was estimated to describe ecosystem properties using the model to assess the maturity and stability of the ecosystem, such as the ratios of total primary production to total respiration (TPP/TR), total primary production to total biomass (TPP/TB), and total biomass to total throughput (TB/TST) (Christensen et al. 2005).

\section{RESULTS}

\section{Water quality}

The water quality parameters of the 3 sub-lakes are listed in Table S1 in the Supplement. Conductivity, total phosphorus, and $\mathrm{COD}_{\mathrm{Mn}}$ values were significantly lower in the ULA compared to the MLA and LLA ( $\mathrm{p}<0.05)$. Except for transparency, all parameters showed no significant differences between the MLA and LLA ( $p>0.05)$.

\section{Basic input and output variables}

The basic input variables of the 3 sub-lakes and the whole of Lake Shangshe were calculated using Eqs. (1) to (8) and the values given in Table 3 \& Table S3 in the Supplement. The pedigree index (0.488) fell in the upper range $(0.164-0.675)$ in all $150 \mathrm{EwE}$ models (Morissette et al. 2006), and the measure of fit was 2.304. This information supports that the input parameters of the models were based on reliable sources and that the model was robust with high confidence. A set of estimated parameters from the model is listed in Table 3. The EE values were estimated to be $>0.5$ for commercial fish groups such as silver carp (0.933), bighead carp (0.931), grass carp (0.718), common carp (0.823), and bream (0.735) in Lake Shangshe. However, the EE values of small

Table 3. Basic input (not bold) and estimated parameters (bold) in the model of Lake Shangshe. P/B: production/biomass ratio;

\begin{tabular}{|c|c|c|c|c|c|c|c|}
\hline Functional group & Code & $\begin{array}{l}\text { Fractional } \\
\text { trophic level }\end{array}$ & $\begin{array}{l}\text { Biomass } \\
\left(\mathrm{t} \mathrm{km}^{-2}\right)\end{array}$ & $\begin{array}{c}P / B \\
\left(\mathrm{yr}^{-1}\right)\end{array}$ & $\begin{array}{c}Q / B \\
\left(\mathrm{yr}^{-1}\right)\end{array}$ & $\mathrm{EE}$ & $P / Q$ \\
\hline Mandarin fish & ManF & 3.22 & 0.30 & 1.04 & 3.27 & 0.721 & 0.318 \\
\hline Snakehead fish & SnaF & 3.27 & 0.33 & 0.96 & 3.36 & 0.496 & 0.285 \\
\hline Topmouth culter & TopC & 3.25 & 0.31 & 1.28 & 4.22 & 0.756 & 0.303 \\
\hline Other culters & OthC & 3.17 & 1.58 & 1.25 & 6.94 & 0.579 & 0.180 \\
\hline Common carp & ComC & 2.06 & 4.65 & 2.04 & 8.37 & 0.823 & 0.244 \\
\hline Crucian carp & CruC & 2.27 & 1.72 & 2.57 & 15.92 & 0.619 & 0.161 \\
\hline Small pelagic fishes & SmaP & 2.02 & 7.18 & 2.59 & 25.67 & 0.266 & 0.101 \\
\hline Small demersal fishes & SmaD & 2.22 & 6.21 & 2.18 & 15.58 & 0.408 & 0.140 \\
\hline Silver carp & $\mathrm{SilC}$ & 2.20 & 5.28 & 3.31 & 11.84 & 0.933 & 0.279 \\
\hline Bighead carp & BigC & 2.92 & 4.95 & 4.56 & 7.65 & 0.931 & 0.596 \\
\hline Grass carp & GraC & 2.00 & 8.84 & 1.09 & 13.60 & 0.718 & 0.080 \\
\hline Bream & Brea & 2.01 & 1.88 & 1.66 & 21.78 & 0.735 & 0.076 \\
\hline Shrimp & Shri & 2.19 & 1.22 & 2.50 & 12.50 & 0.379 & 0.200 \\
\hline Zoobenthos & Zoob & 2.00 & 2.59 & 15.00 & 300.00 & 0.625 & 0.050 \\
\hline Microzooplankton & Mizo & 2.00 & 6.15 & 8.38 & 167.51 & 0.950 & 0.050 \\
\hline Cladocera & Clad & 2.02 & 0.14 & 5.44 & 108.88 & 0.900 & 0.050 \\
\hline Copepoda & Cope & 2.02 & 0.13 & 4.60 & 92.07 & 0.900 & 0.050 \\
\hline Cyanobacteria & Cyan & 1.00 & 9.06 & 150.00 & - & 0.105 & - \\
\hline Other phytoplankton & OthP & 1.00 & 8.80 & 219.44 & - & 0.494 & - \\
\hline Millet grass & MilG & 1.00 & 268.18 & _- & - & 0.544 & - \\
\hline Detritus & Detr & 1.00 & 83.22 & - & - & 0.417 & - \\
\hline
\end{tabular}
$Q / B$ : consumption/biomass ratio; EE: ecotrophic efficiency; $P / Q$ : production/consumption ratio; -: no data 
pelagic fishes (0.266) and cyanobacteria (0.105) were noticeably lower than those of all other functional groups.

\section{Trophic structure and energy flows}

The fractional trophic levels (FTLs) of all of the 21 functional groups in Lake Shangshe ranged from 1.00 (cyanobacteria, other phytoplankton, millet grass, and detritus) to 3.27 (snakehead fish) (Table 3). A concise web-like representation was developed to show the FTLs of functional groups and energy flows in the lake food webs (Fig. 2A).

To describe the proportion of energy transferred from one trophic level to the next, all of the functional groups in the models were assigned to 1 of 5 aggregated trophic levels (ATLs, Fig. 2). Table 4 shows the ATL decomposition of the groups in the Lake Shangshe ecosystem. Flows at ATL I involved groups of cyanobacteria, other phytoplankton, millet grass, and detritus. ATL II included zooplankton, zoobenthos, shrimp, silver carp, small fishes, herbivorous fishes, and omnivorous fishes. ATL III contained mandarin fish, snakehead fish, topmouth culter, other culters, and bighead carp. Crucian carp, small demersal fishes, silver carp, and shrimp were also partly involved in the flows at ATL III. Flows at ATL IV and ATL V were dominated by predators (mandarin fish, snakehead fish, and topmouth culter). From the Lindeman spine of lakes, a detritus-based food chain and a grazing food chain were detected (Fig. 2B). For the grazing food chain of the Lake Shangshe ecosystem, the transfer efficiencies (TEs) from ATL II to ATL III, ATL III to ATL IV, ATL IV to ATL V were 5.8, 25.5 , and $17.3 \%$, respectively, with a mean value of $13.7 \%$. For the detrital food chain, TEs were 4.9, 30.9, and $23.5 \%$, respectively, with a mean value of $15.2 \%$. The total mean TE of the Lake Shangshe ecosystem was $14.4 \%$.

A
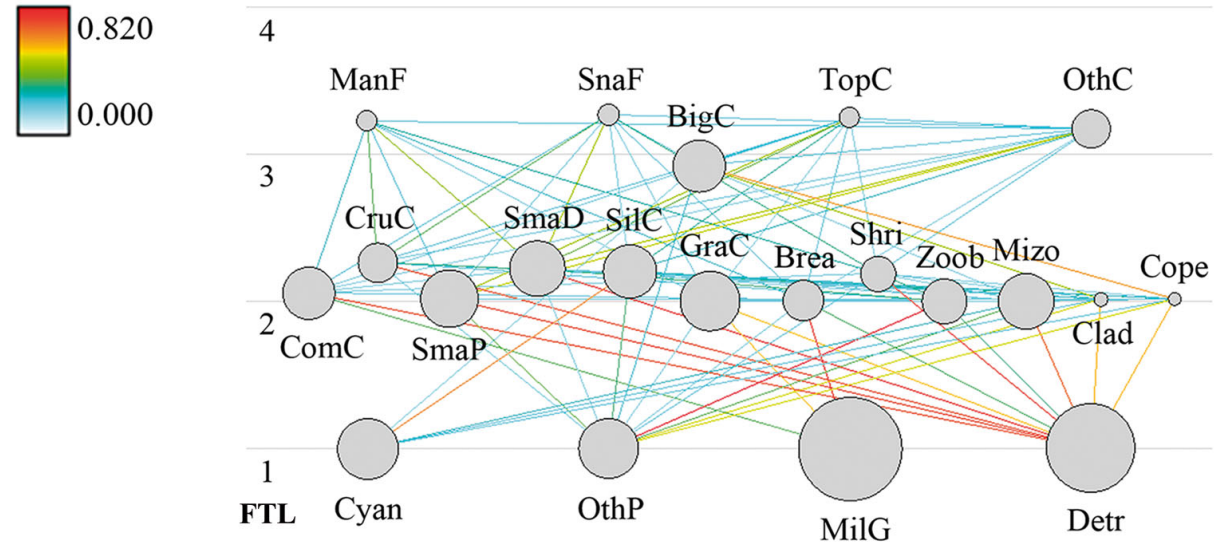

B

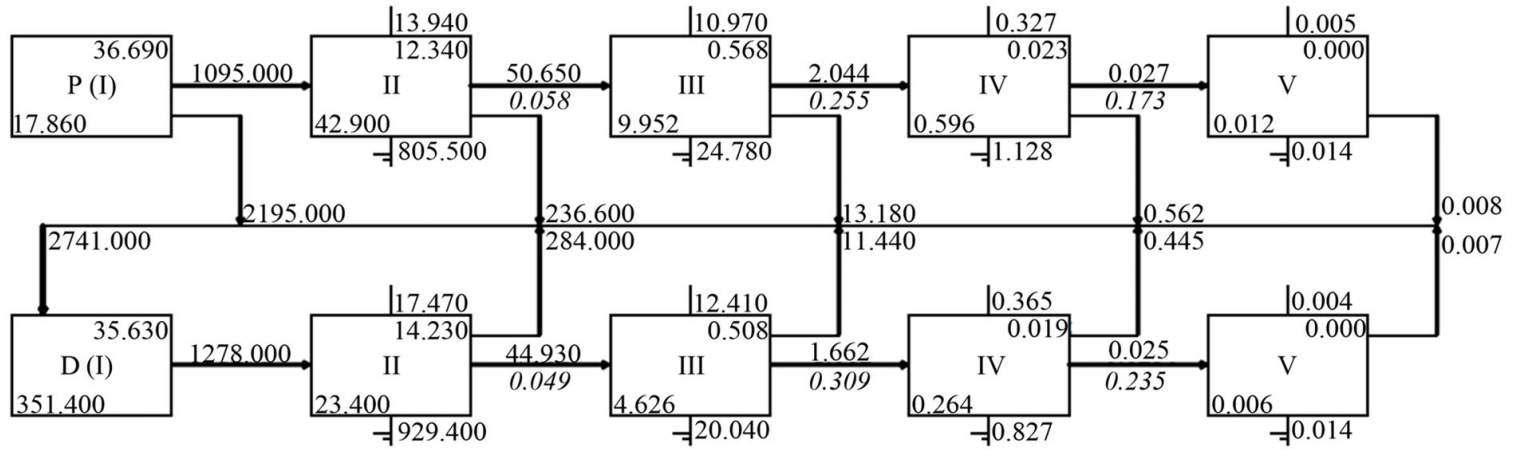

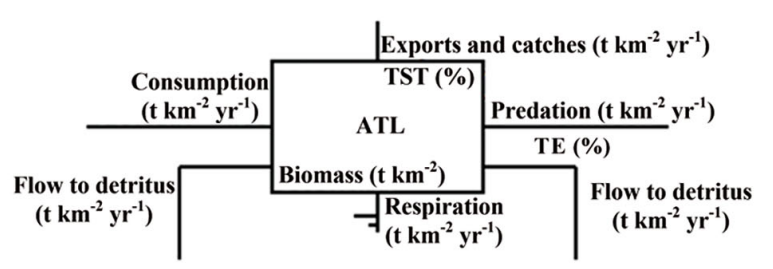

Fig. 2. (A) Food web structure and trophic flows and (B) Lindeman spine of the Lake Shangshe ecosystem. (A) The circles represent functional groups; circle sizes are proportional to biomass $\left(\mathrm{t} \mathrm{km}^{-2}\right)$; lines reflect trophic flows; color key (dimensionless) represents the proportion that the prey contributed to a predator's diet; FTL: fractional trophic level; group abbreviations as in Table 3. (B) P: primary producers; D: detritus; I to V: aggregated trophic levels (ATLs); TE: transfer efficiency; TST: total system throughput; exports and catches: harvest of cultured fishes 
Table 4. Aggregated trophic level decomposition of the functional groups in the Lake Shangshe ecosystem. -: no data

\begin{tabular}{|c|c|c|c|c|c|}
\hline \multirow[t]{2}{*}{ Functional group } & \multicolumn{5}{|c|}{ Aggregated trophic level- } \\
\hline & I & II & III & IV & $\mathrm{V}$ \\
\hline Mandarin fish & - & _- & 0.786 & 0.204 & 0.010 \\
\hline Snakehead fish & - & - & 0.742 & 0.248 & 0.011 \\
\hline Topmouth culter & - & - & 0.765 & 0.224 & 0.011 \\
\hline Other culters & - & - & 0.829 & 0.169 & 0.001 \\
\hline Common carp & - & 0.945 & 0.051 & 0.004 & - \\
\hline Crucian carp & - & 0.737 & 0.259 & 0.003 & - \\
\hline Small pelagic fishes & - & 0.982 & 0.018 & 0.000 & - \\
\hline Small demersal fishes & - & 0.777 & 0.222 & 0.001 & - \\
\hline Silver carp & - & 0.800 & 0.197 & 0.003 & - \\
\hline Bighead carp & - & 0.091 & 0.894 & 0.015 & - \\
\hline Grass carp & - & 0.998 & 0.002 & - & - \\
\hline Bream & - & 0.994 & 0.006 & - & - \\
\hline Shrimp & - & 0.810 & 0.190 & - & - \\
\hline Zoobenthos & - & -1.000 & - & - & - \\
\hline Microzooplankton & - & -1.000 & - & - & - \\
\hline Cladocera & - & 0.984 & 0.016 & - & - \\
\hline Copepoda & - & 0.984 & 0.016 & - & - \\
\hline Cyanobacteria & 1.000 & - & - & - & - \\
\hline Other phytoplankton & 1.000 & - & - & - & - \\
\hline Millet grass & 1.000 & - & - & - & - \\
\hline Detritus & 1.000 & - & - & - & - \\
\hline
\end{tabular}

\section{Prey overlap indices and mixed trophic impacts}

Table 5 shows the prey overlap indices between the functional groups of Lake Shangshe. The prey overlap indices between small pelagic fishes and stocked fishes (common carp, crucian carp, and grass carp) were $0.90,0.93$, and 0.66 , respectively. The results of mixed trophic impacts (MTIs) exhibited both positive and negative effects on each other (Fig. 3). The main food sources (e.g. detritus and millet grass) had posi- tive effects on other groups, especially common carp, crucian carp, grass carp, and bream. The other compartments showed direct predator-prey interactions, cascading effects, and competition. Filter-feeding fishes (e.g. silver carp and bighead carp) had negative effects on cyanobacteria, Cladocera, and Copepoda. Piscivorous fishes (such as mandarin fish, snakehead carp, topmouth culter, and other culters) had negative effects on forage fishes (e.g. small pelagic fishes and small demersal fishes). The fishery (fleet group) had relatively strong negative effects on all commercial fishes (such as piscivorous fishes, silver carp, bighead carp, and grass carp) but was beneficial for small pelagic fishes, small demersal fishes, shrimp, zooplankton, and cyanobacteria.

\section{Ecosystem properties}

The ecosystem properties of Lake Shangshe are listed in Table 6. The TPP/TR, TPP/TB, and TB/TST values were $1.847,46.131$, and 0.008 , respectively.

\section{DISCUSSION}

\section{Trophic structure and energy flows}

In this study, a set of indicators was derived by the model to analyze the trophic structure and energy flows of Lake Shangshe, China. One of the most prominent features of the trophic structure was variation in the estimated EE values (Table 3). EE values are the fractions of production that are consumed by

Table 5. Predator overlap indices between functional groups in the Lake Shangshe ecosystem. -: no data

\begin{tabular}{|c|c|c|c|c|c|c|c|c|c|c|c|c|c|c|c|c|c|c|}
\hline & Functional group & 1 & 2 & 3 & 4 & 5 & 6 & 7 & 8 & 9 & 10 & 11 & 12 & 13 & 14 & 15 & 16 & 17 \\
\hline 1 & Mandarin fish & 1.00 & - & - & - & - & - & - & - & - & - & - & - & - & - & - & - & - \\
\hline 2 & Snakehead fish & 0.98 & 1.00 & - & - & - & - & - & - & - & - & - & - & - & - & - & - & - \\
\hline 3 & Topmouth culter & 0.59 & 0.56 & 1.00 & - & - & - & - & - & - & - & - & - & - & - & - & - & - \\
\hline 4 & Other culters & 0.61 & 0.60 & 0.95 & 1.00 & - & - & - & - & - & - & - & - & - & - & - & - & - \\
\hline 5 & Common carp & 0.01 & 0.01 & 0.01 & 0.01 & 1.00 & - & - & - & - & - & - & - & - & - & - & - & - \\
\hline 6 & Crucian carp & - & - & - & - & 0.92 & 1.00 & - & - & - & - & - & - & - & - & - & - & - \\
\hline 7 & Small pelagic fishes & - & - & - & - & 0.90 & 0.93 & 1.00 & - & - & - & - & - & - & - & - & - & - \\
\hline 8 & Small demersal fishes & - & - & - & - & 0.93 & 0.96 & 0.92 & 1.00 & - & - & - & - & - & - & - & - & - \\
\hline 9 & Silver carp & - & - & - & - & - & 0.05 & 0.10 & 0.01 & 1.00 & - & - & - & - & - & - & - & - \\
\hline 10 & Bighead carp & - & - & - & - & - & 0.23 & 0.06 & 0.03 & 0.25 & 1.00 & - & - & - & - & - & - & - \\
\hline 11 & Grass carp & - & - & - & - & 0.88 & 0.68 & 0.66 & 0.68 & - & - & 1.00 & - & - & - & - & - & - \\
\hline 12 & Bream & - & - & - & - & 0.55 & 0.26 & 0.26 & 0.26 & - & - & 0.87 & 1.00 & - & - & - & - & - \\
\hline 13 & Shrimp & - & - & - & - & 0.94 & 0.96 & 0.94 & 1.00 & 0.02 & 0.02 & 0.68 & 0.26 & 1.00 & - & - & - & - \\
\hline 14 & Zoobenthos & - & - & - & - & 0.20 & 0.23 & 0.52 & 0.22 & 0.29 & 0.12 & 0.15 & 0.07 & 0.27 & 1.00 & - & - & - \\
\hline 15 & Microzooplankton & - & - & - & - & 0.89 & 0.91 & 0.99 & 0.91 & 0.23 & 0.04 & 0.66 & 0.25 & 0.93 & 0.51 & 1.00 & - & - \\
\hline 16 & Cladocera & - & - & - & - & 0.72 & 0.75 & 0.92 & 0.74 & 0.27 & 0.08 & 0.54 & 0.21 & 0.78 & 0.77 & 0.93 & 1.00 & - \\
\hline 17 & Copepoda & - & - & - & - & 0.72 & 0.75 & 0.92 & 0.74 & 0.27 & 0.08 & 0.54 & 0.21 & 0.78 & 0.77 & 0.93 & 1.00 & 1.00 \\
\hline
\end{tabular}




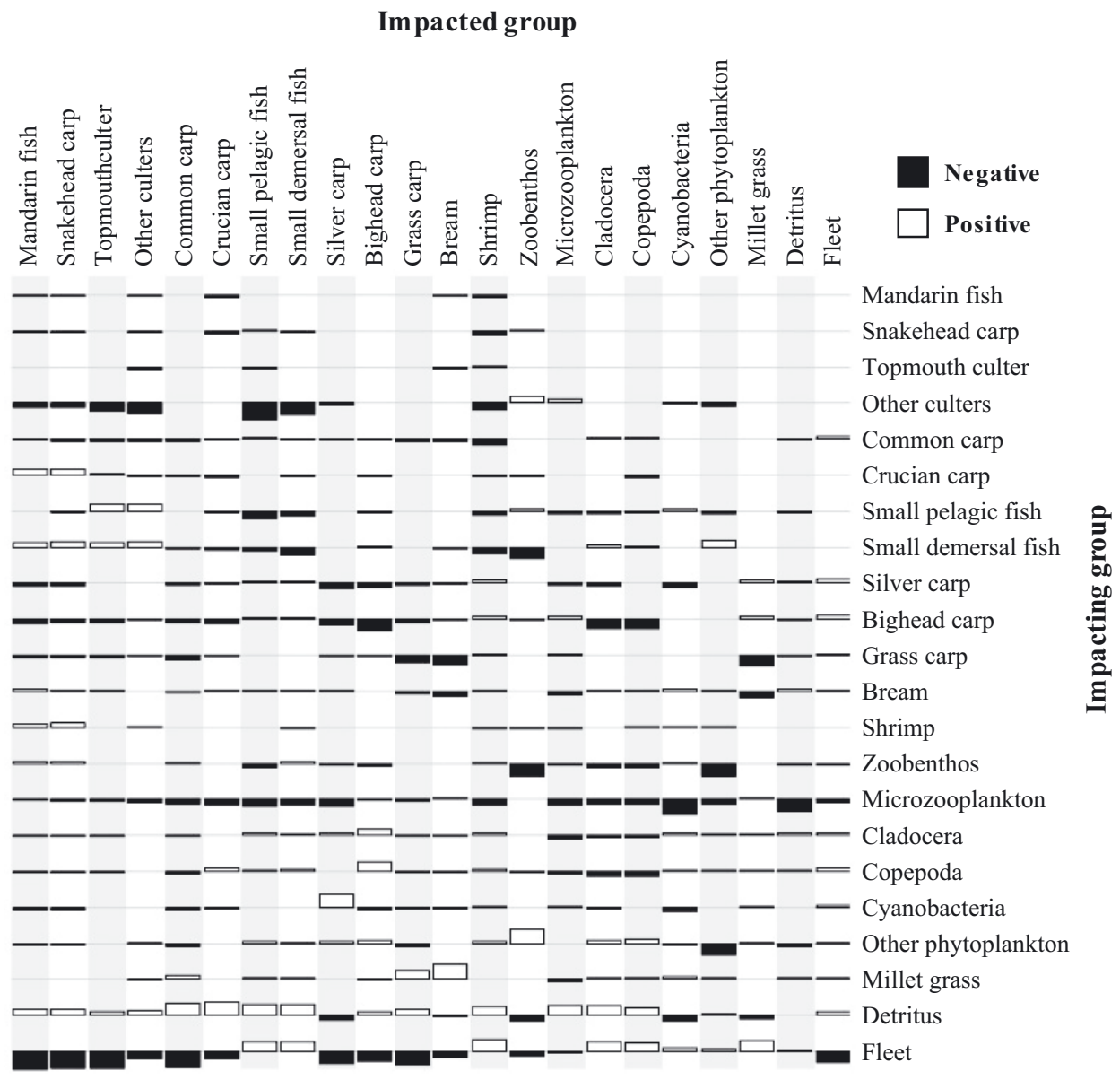

Fig. 3. Mixed trophic impacts of the Lake Shangshe ecosystem. The black bars pointing downwards show the negative impact on the functional groups, while the white bars pointing upwards indicate the positive impacts. The heights of the bars are proportionate to the degree of the impact, and values range from -1 to +1

predators within the system or exported out of the system through fishing (Coll et al. 2009). The high EE values of fish groups showed that fishing activities and predation pressure negatively impacted the fishes. In the Lake Shangshe ecosystem, EE values were estimated to be $>0.5$ for the commercial fish groups (including silver carp, bighead carp, grass carp, common carp, mandarin fish, and topmouth culter). These results were consistent with the fisheries yield of Lake Shangshe between 2014 and 2015, which showed that commercial fishes were the main fishing targets, accounting for $93.7 \%$ of the total fisheries yield (55.48 t km${ }^{-2}$, Fig. S1). Similar results were observed in other lakes and ponds where the EE values of stocked commercial fishes (such as silver carp, bighead carp, and grass carp) were higher than 0.9 (Liu et al. 2007, Zhou et al. 2015, Kong et al. 2016).

In comparison, the estimated EE values of small pelagic fishes and cyanobacteria were extremely low, indicating that these groups were not well uti- lized in the Lake Shangshe ecosystem. The prey overlap index was calculated to determine the consumed extent of 2 functional groups for the same

Table 6. Ecosystem properties of the Lake Shangshe ecosystem

\begin{tabular}{|lc|}
\hline Parameter & Lake Shangshe \\
\hline Sum of all exports $\left(\mathrm{t} \mathrm{km} \mathrm{km}^{-2} \mathrm{yr}^{-1}\right)$ & 1703.039 \\
Sum of all consumption $\left(\mathrm{t} \mathrm{km}^{-2} \mathrm{yr}^{-1}\right)$ & 2473.011 \\
Sum of all respiratory flows $\left(\mathrm{t} \mathrm{km}^{-2} \mathrm{yr}^{-1}\right)$ & 1781.766 \\
Sum of all flows into detritus $\left(\mathrm{t} \mathrm{km}^{-2} \mathrm{yr}^{-1}\right)$ & 3010.137 \\
Sum of all production $\left(\mathrm{t} \mathrm{km}^{-2} \mathrm{yr}^{-1}\right)$ & 3486.715 \\
Total system throughput $\left(\mathrm{t} \mathrm{km}^{-2} \mathrm{yr}^{-1}\right)$ & 8967.953 \\
Total biomass (excluding detritus) $\left(\mathrm{t} \mathrm{km}^{-2}\right)$ & 71.320 \\
Total primary production/total respiration & 1.847 \\
Total primary production/total biomass & 46.131 \\
Total biomass/total throughput & 0.008 \\
Pedigree index & 0.488 \\
Measure of fit $\left(t^{*}\right)$ & 2.304 \\
\hline
\end{tabular}


prey (Table S4 in the Supplement). This index is symmetrical, and its values ranged between 0 and 1 . A value of 0 indicates that the 2 species do not compete for the same prey, whereas a value of 1 indicates complete overlap. Intermediate values indicate partial overlaps in resource utilization between the functional groups (Christensen \& Walters 2004). The values of the predator overlap indices between small pelagic fishes and commercial fishes (common carp, crucian carp, and grass carp) were relatively higher (0.90, 0.93, and 0.66, respectively) (Table 5). Thus, competition for prey resources among these species will lead to less energy being transferred to fishery products. In addition to their competition for food with economically important fishes, small pelagic fishes are of low economic value, and some of them feed on the eggs and fry of other species (Li \& Xu 1995). Therefore, stock enhancement of piscivorous fishes to eliminate these unwanted species is urgently needed. In addition to economic benefits, silver carp Hypophthalmichthys molitrix and bighead carp $H$. nobilis are also useful for controlling algal blooms, because of their abilities to ingest masses of phytoplankton directly and to adjust the water environment (Xie 2003, Guo et al. 2015). Artificial stock enhancement of silver carp and bighead carp to control cyanobacterial blooms has been tested and used successfully in many eutrophic lakes in China, such as Lake Donghu (Xie \& Liu 2001) and Lake Qiandao (Liu et al. 2007). Various studies have demonstrated that the stocking density and ratio between silver carp and bighead carp can be used to control cyanobacteria levels (Xie \& Liu 2001, Yi et al. 2016). Silver carp and bighead carp reared at 30 to $70 \mathrm{~g} \mathrm{~m}^{-3}$ provide the most effective way of preventing the rapid growth of algae, with a proportion of $>2.33$ silver carp being recommended for use (Zhang et al. 2008, Yi et al. 2016). In the present study, the density of silver carp and bighead carp was $4.87 \mathrm{~g} \mathrm{~m}^{-3}$ and the ratio was 1.07. These were lower than the recommended values. Therefore, to enhance the EE value of cyanobacteria and the TE in Lake Shangshe, the stocking strategies of silver carp and bighead carp need to be optimized.

The MTI routine, described by Ulanowicz \& Puccia (1990), is used to determine the trophic interactions of one functional group with the other groups in an ecosystem (Christensen \& Walters 2004, our Table S4). In the Lake Shangshe ecosystem, MTI analyses showed that fishing pressure was higher on top predators (i.e. mandarin fish, snakehead fish, and topmouth culter) than on other species and had positive impacts on small fish resources under the effects of fish selectivity and trophic cascades, which was consistent with fisheries yield composition (Fig. S1). The EE values combined with MTI analyses demonstrated that fishing pressure on piscivorous fishes was high. Furthermore, optimizing capture strategies is essential when stock enhancement is implemented.

TEs are the ratios between the sum of exports and flows predated on by the next level and the throughput on the trophic level (Table S4). ATL III included mandarin fish, snakehead fish, topmouth culter, other culters, and bighead carp (Table 4). Consistent with the high EE values for these species, the TE value increased significantly from ATL III to ATL IV. The EwE model has been established for numerous lakes to assess energy flows in aquatic ecosystems. Compared with other lakes in China, the total mean TE of the Lake Shangshe ecosystem was relatively higher, indicating that primary production was efficiently utilized; thus, more nutrients were transferred to fishery products (Table 7).

\section{Assessment of ecosystem maturity}

According to the ecosystem development described by Odum (1969) and Christensen (1995), energy that is fixed tends to be balanced by the energy cost of maintenance. Thus, TPP/TR is $>1$ in the immature ecosystem and will approach 1 when the ecosystem becomes mature. As long as TPP exceeds TR, biomass will accumulate in the system, which will lead to a decrease in TPP/TB (Odum 1969). Therefore, the TPP/TB ratio is lower in a mature system than in a developing system. According to Ulanowicz (1986), the TB/TST ratio is expected to increase as systems mature.

The EwE model has been constructed for many lakes to assess the maturity of aquatic ecosystems (Table 8 ). The TPP/TR ratio was 1.847 in the Lake Shangshe ecosystem. This ratio was lower than that of most lakes in China, including Lakes Qiandao (1999-2000, 2004), Taihu (1991-1995), Gehu (19861989), Chaohu (2007-2010, 2000s), Niushan (20022004), and Ehai (2009-2012). In addition, this ratio was higher than that obtained for lakes Taihu (19611965, 1981-1987), Wuli (2009), Bao'an (1992-1993), Dianchi (2009-2010), Chaohu (1950s, 1980s), and Wuhu (2006-2007, 2008-2011). The TPP/TB ratio of the Lake Shangshe ecosystem was 46.131 ; between the immature lake ecosystem (Lake Chaohu, 20072010) and the mature ecosystem (Lake Gehu, 19861989). The TB/TST ratio in this study was 0.008 ; 
Table 7. Transfer efficiencies (from primary producers, from detritus, and total mean) of lake ecosystems in China. -: no data

\begin{tabular}{|c|c|c|c|c|c|}
\hline Lake & Period & $\begin{array}{c}\text { Primary } \\
\text { producers }(\%)\end{array}$ & $\begin{array}{l}\text { Detritus } \\
(\%)\end{array}$ & $\begin{array}{l}\text { Mean } \\
(\%)\end{array}$ & Source \\
\hline Shangshe & 2014-2015 & 13.7 & 15.2 & 14.4 & Present study \\
\hline Qiandao & 2004 & 3.5 & 2.1 & 2.7 & Liu et al. (2007) \\
\hline Wuli & 2009 & 4.8 & 4.1 & 5.7 & Huang et al. (2012) \\
\hline Gehu & 1986-1989 & - & - & 12.35 & Jia et al. (2012) \\
\hline Bao'an & 1992-1993 & 8.96 & 8.40 & 8.68 & Guo et al. (2013) \\
\hline Dianchi & 2009-2010 & 5.1 & 4.9 & 4.9 & Shan et al. (2014) \\
\hline Chaohu & $2007-2010$ & 6.9 & 6.8 & 6.9 & Liu et al. (2014) \\
\hline Chaohu & $1950 \mathrm{~s}$ & 14.5 & 13.6 & 14.0 & Kong et al. (2016) \\
\hline Chaohu & $1980 \mathrm{~s}$ & 10.7 & 9.1 & 9.8 & Kong et al. (2016) \\
\hline Chaohu & $2000 s$ & 8.7 & 8.7 & 8.7 & Kong et al. (2016) \\
\hline Niushan & 2002-2004 & - & - & 13.5 & Ye $(2007)$ \\
\hline Wuhu & $2006-2007$ & - & - & 10.0 & Lin (2012) \\
\hline Wuhu & $2006-2007$ & - & - & 12.1 & Lin (2012) \\
\hline Ehai & 2009-2012 & - & - & 8.3 & Tang (2013) \\
\hline
\end{tabular}

\section{Suggestions for improvements of CBF practice}

It is widely accepted that an ecosystem-based approach to lake ecosystem fisheries management is relevant for sustainable fisheries and the maintenance of healthy ecosystems. Through analyses of trophic structure and energy flows in Lake Shangshe, ecosystemoriented fisheries management strategies have emerged.

First, due to the low EE value of small pelagic fishes, stock enhancement of piscivorous fishes is urgently needed. The fish species that are selected for CBF should have fast growth and

between the immature ecosystem (Lake Chaohu, 2007-2010; Lake Chaohu, 2000s) and the mature ecosystem (Lake Bao'an, 1992-1993; Lake Chaohu, 1950s). Thus, the Lake Shangshe ecosystem is a relatively mature ecosystem compared to other immature (Lake Qiandao, 2004; Lake Chaohu, 2007-2010, 2000s) and mature (Lake Wuli, 2009; Lake Bao'an, 1992-1993) ecosystems (Q. Liu et al. 2007, 2010, Ye 2007, Huang et al. 2012, Jia et al. 2012, Lin 2012, Guo et al. 2013, Tang 2013, E. Liu et al. 2014, Shan et al. 2014, Kong et al. 2016).

Table 8. Ecosystem properties of lake ecosystems in China. TPP: total primary production; TR: total respiration; TB: total biomass; TST: total throughput. -: no data

\begin{tabular}{|lccccl|}
\hline Lake & Period & TPP/TR & TPP/TB & TB/TST & Source \\
& & & & & \\
\hline Shangshe & $2014-2015$ & 1.847 & 46.131 & 0.008 & Present study \\
Qiandao & $1999-2000$ & 2.073 & 89.598 & 0.003 & Liu et al. (2010) \\
Qiandao & 2004 & 3.725 & 73.956 & 0.004 & Liu et al. (2007) \\
Taihu & $1961-1965$ & 1.50 & 5.46 & 0.04 & Li et al. (2010) \\
Taihu & $1981-1987$ & 1.47 & 6.97 & 0.03 & Li et al. (2010) \\
Taihu & $1991-1995$ & 3.85 & 11.66 & 0.03 & Li et al. (2010) \\
Wuli & 2009 & 1.339 & 10.431 & 0.029 & Huang et al. (2012) \\
Gehu & $1986-1989$ & 2.761 & 1.76 & - & Jia et al. (2012) \\
Bao'an & $1992-1993$ & 1.640 & 6.993 & 0.049 & Guo et al. (2013) \\
Dianchi & $2009-2010$ & 1.665 & 61.812 & 0.003 & Shan et al. (2014) \\
Chaohu & $2007-2010$ & 13.53 & 137.92 & 0.003 & Liu et al. (2014) \\
Chaohu & $1950 \mathrm{~s}$ & 0.971 & 8.864 & 0.042 & Kong et al. (2016) \\
Chaohu & $1980 \mathrm{~s}$ & 1.629 & 54.858 & 0.007 & Kong et al. (2016) \\
Chaohu & $2000 \mathrm{~s}$ & 2.132 & 111.154 & 0.004 & Kong et al. (2016) \\
Niushan & $2002-2004$ & 2.642 & - & - & Ye (2007) \\
Wuhu & $2006-2007$ & 1.458 & 9.164 & 0.037 & Lin (2012) \\
Wuhu & $2008-20011$ & 1.359 & 5.004 & 0.067 & Lin (2012) \\
Ehai & $2009-2012$ & 9.952 & 5.178 & 0.056 & Tang (2013) \\
\hline
\end{tabular}

high economic value, feed on a wide range of food types, and have an easily available and reliable supply of fry. Moreover, such species should not harm other economically important fish species (Li \& Xu 1995). Topmouth culter is an indigenous species that feeds on small fishes in the middle and upper layers of open waters (Li \& Xu 1995, Zhang 2005), and it has almost no negative effects on stocked fishes according to the MTI results (Fig. 3). Therefore, stocking of topmouth culter in Lake Shangshe is recommended. CBF practices are dependent on regular stocking. Excess stocking results in decreased growth and/or increased mortality, leading to lower yields (De Silva 2003). Thus, it is important to estimate the carrying capacity by calculating the biomass and production of small fishes and their bioenergetics before stocking lakes with topmouth culter. The addition of seed stock to a water body with the view of enhancing fish production is only one facet of stock enhancement. Stock enhancement also includes other practices, such as the introduction of closed seasons, gear restrictions, establishment of conservation zones, and improvement and/or establishment of spawning grounds (De Silva et al. 2015). Our EE and MTI outputs demonstrate that greater effort should be placed on optimizing capture strategies that reduce pressure on piscivorous fishes 
in Lake Shangshe, especially for juvenile (young) stages. Because of the low EE value of cyanobacteria, stronger focus should be placed on how primary production is utilized to enhance the TE and water quality of the Lake Shangshe ecosystem. Consistent with the utilization of cyanobacteria, high stocking density and proportion of silver carp H. molitrix in Lake Shangshe appear to be favorable at present.

From the perspectives of the ecosystem model and water quality assessment, implementation of these CBF practices, considering ecosystem services and the direction of water flow, has a positive effect on the ecosystem health of Lake Shangshe. Our results are expected to contribute towards maintaining the sustainability of fisheries in our study lake while potentially serving as a reference for other lakes where the traditional stocking of Asian carp remains a popular practice.

Acknowledgements. The present study was supported by the Special Fund for Agro-scientific Research in the Public Interest of China (No. 201303056), National Key Technology Research and Development Program of China (No. 2012 BAD25B08) and Special Fund for Technical Innovation of Hubei Province (No. 2017ABA061). We thank Editage for English language editing.

\section{LITERATURE CITED}

Allen KR (1971) Relation between production and biomass. J Fish Res Board Can 28:1573-1581

APHA (American Public Health Association) (1992) Standard methods for the examination of water and wastewater, 18th edn. APHA, Washington, DC

Barko JW, James WF (1998) Effects of submerged aquatic macrophytes on nutrient dynamics, sedimentation, and resuspension. In: Jeppesen E, Søndergaard M, Søndergaard M, Christoffersen K (eds) The structuring role of submerged macrophytes in lakes. Springer, New York, NY, p 197-214

Beverton RJH, Holt SJ (1957) On the dynamics of exploited fish populations. Springer, Dordrecht

Bird DF, Kalff J (1984) Empirical relationships between bacterial abundance and chlorophyll concentration in fresh and marine waters. Can J Fish Aquat Sci 41:1015-1023

Boyd CE (1970) Production, mineral nutrient accumulation and pigment concentration in Typha latifolia and Scirpus americanus. Ecology 51:285-290

Carpenter SR, Donk EV, Wetzel RG (1998) Nutrient-loading gradient in shallow lakes: report of the group discussion. In: Jeppesen E, Søndergaard M, Søndergaard M, Christoffersen K (eds) The structuring role of submerged macrophytes in lakes. Springer, New York, NY, p 393-396

Chea R, Guo CB, Grenouillet G, Lek S (2016) Toward an ecological understanding of a flood-pulse system lake in a tropical ecosystem: food web structure and ecosystem health. Ecol Modell 323:1-11

Chen ZZ, Qiu YS, Jia XP (2006) Mass-balance Ecopath model of Beibu Gulf ecosystem. Ying Yong Sheng Tai
Xue Bao 17:1107-1111 (in Chinese with English Abstract) Cheng HH, Li DP, Xie CX, Tian X, He XG (2015) Cultivating grass carp with grass planted in the square ponds around can promote energy conservation and emission reduction effectively. Sci Fish Farm 10:20-21 (in Chinese)

Cheng HH, Xie CX, Li DP, Xiao YH and others (2016) The study of muscular nutritional components and fish quality of grass carp (Ctenopharyngodon idella) in ecological model of cultivating grass carp with grass. Shuichan Xuebao 40:1050-1059 (in Chinese with English Abstract)

Cho BC, Azam F (1990) Biogeochemical significance of bacterial biomass in the ocean's euphotic zone. Mar Ecol Prog Ser 63:253-259

Christensen V (1995) Ecosystem maturity-towards quantification. Ecol Modell 77:3-32

Christensen V, Walters CJ (2004) Ecopath with Ecosim: methods, capabilities and limitation. Ecol Modell 172: 109-139

Christensen V, Walters CJ, Pauly D (2005) Ecopath with Ecosim: a user's guide. Fisheries Centre, University of British Columbia, Vancouver, p 10-13

Coll M, Bundy A, Shannon LJ (2009) Ecosystem modelling using the Ecopath with Ecosim approach. In: Megrey BA, Moksness E (eds) Computers in fisheries research. Springer, Berlin, p 225-291

De Silva SS (2003) Culture-based fisheries: an underutilised opportunity in aquaculture development. Aquaculture 221:221-243

De Silva SS, Ingram BA, Wilkinson S (2015) Perspectives on culture-based fisheries developments in Asia. Scandmedia, Bangkok

* Dhote S, Dixit S (2009) Water quality improvement through macrophytes-a review. Environ Monit Assess 152: 149-153

FAO (Food and Agricultural Organization of the United Nations) (2017) The capture, aquaculture and global production databases. www.fao.org/fishery/statistics/en (accessed March 2017)

*Finn JT (1976) Measures of ecosystem structure and function derived from analysis of flows. J Theor Biol 56: 363-380

Gong LJ, Wen ZR, Xia C, Zhang HG, Zeng MK (1992) The growth condition of silver carp cultivating with grass in the lakebed. Freshw Fish 4:36-38 (in Chinese)

*Guo CB, Ye SW, Lek S, Liu JS, Zhang TL, Yuan J, Li ZJ (2013) The need for improved fishery management in a shallow macrophytic lake in the Yangtze River Basin: evidence from the food web structure and ecosystem analysis. Ecol Modell 267:138-147

Guo LG, Wang Q, Xie P, Tao M, Zhang J, Niu Y, Ma ZM (2015) A non-classical biomanipulation experiment in Gonghu Bay of Lake Taihu: control of microcystis blooms using silver and bighead carp. Aquacult Res 46: 2211-2224

*Heymans JJ, Shannon LJ, Jarre A (2004) Changes in northern Benguela ecosystem over three decades: 1970s, 1980s, and 1990s. Ecol Modell 172:175-195

Huang XF (1999) Survey, observation and analysis of lake ecology. Standards Press of China, Beijing (in Chinese)

Huang XF, Bing XW, Chen JC (2012) The preliminary research of energy flow model on Lake Wuli ecosystem. Shanghai Haiyang Daxue Xuebao 21:78-85 (in Chinese with English Abstract)

Ingram BA, De Silva SS (2015) General aspects of stock enhancement in fisheries developments. In: De Silva SS, 
Ingram BA, Wilkinson S (eds) Perspectives on culturebased fisheries developments in Asia. Scandmedia, Bangkok, p 27-37

Jeppesen E, Søndergaard M, Jensen JP, Kanstrup E, Petersen B (1998) Macrophytes and turbidity in brackish lakes with special emphasis on the role of top-down control. In: Jeppesen E, Søndergaard M, Søndergaard M, Christoffersen K (eds) The structuring role of submerged macrophytes in lakes. Springer, New York, NY, p 369-377

Jia PQ, Hu MH, Hu ZJ, Liu QG, Wu Z (2012) Modeling trophic structure and energy flows in a typical macrophyte dominated shallow lake using the mass balanced model. Ecol Modell 233:26-30

Kitchell JF, Cox SP, Harvey CJ, Johnson TB and others (2000) Sustainability of the Lake Superior fish community: interactions in a food web context. Ecosystems 3:545-560

Kong XZ, He W, Liu WX, Yang B, Xu FL, Jørgensen SE, Mooij WM (2016) Changes in food web structure and ecosystem functioning of a large, shallow Chinese lake during the 1950s, 1980s and 2000s. Ecol Modell 319: $31-41$

Li SF, Xu SL (1995) Culture and capture of fish in Chinese reservoirs. International Development Research Centre and Southbound Sendirian Berhad, Ottawa and Penang

Li YK, Song B, Chen Y, Yu N, Chen LQ (2009) Simulation of ecosystem dynamics of Lake Taihu using Ecopath with Ecosim model. J Fish Sci China 16:257-265 (in Chinese with English Abstract)

Li YK, Song B, Chen Y, Chen LQ, Yu N, Olson D (2010) Changes in the trophic interactions and the community structure of Lake Taihu (China) ecosystem from the 1960s to 1990s. Aquat Ecol 44:337-348

Li YK, Liu ES, Wang H, Gong Y (2014) Analysis on the ecosystem structure and function of Lake Taihu based on Ecopath model. Ying Yong Sheng Tai Xue Bao 25: 2033-2040 (in Chinese with English Abstract)

Lian YX, Liu JS, Chen Y, Yuan J, Li ZJ (2016) Development and reform of lake commercial fisheries in the Yangtze River Basin, China. In: Chen YS, Chapman D, Jackson J, Chen DQ and others (eds) Fishery resources, environment, and conservation in the Mississippi and Yangtze. Am Fish Soc Symp 80:1-12

Lin ML (2012) Studies on stocking techniques of Culter mongolicus and ecosystem effects of piscivorous fish releasing in lakes along the middle and lower reaches of the Yangtze River. PhD dissertation, Institute of Hydrobiology, Chinese Academy of Sciences, Wuhan (in Chinese with English Abstract)

Liu QG, Chen Y, Li JL, Chen LQ (2007) The food web structure and ecosystem properties of a filter-feeding carps dominated deep reservoir ecosystem. Ecol Modell 203: 279-289

Liu QG, Wang YB, Chen LQ, Liu GD (2010) Analysis on the effects of aquatic environment protection oriented (AEPO) fishery on the characteristics of Lake Qiandaohu ecosystem. Resour Environ Yangtze Basin 19:659-665 (in Chinese with English Abstract)

Liu ES, Li YK, Zang RW, Wang H (2014) A preliminary analysis of the ecosystem structure and functioning of Lake Chaohu based on Ecopath model. Shuichan Xuebao 38:417-425 (in Chinese with English Abstract)

Mandal RN, Datta AK, Sarangi N, Mukhopadhyay PK (2010) Diversity of aquatic macrophytes as food and feed components to herbivorous fish-a review. Indian J Fish 57: 65-73
Morissette L, Hammill MO, Savenkoff C (2006) The trophic role of marine mammals in the northern Gulf of St. Lawrence. Mar Mamm Sci 22:74-103

Odum EP (1969) The strategy of ecosystem development. Science 164:262-270

Odum EP, Barrett GW (1971) Fundamentals of ecology. WB Saunders, Philadelphia, PA

* Palomares MLD, Pauly D (1998) Predicting food consumption of fish populations as functions of mortality, food type, morphometrics, temperature and salinity. Mar Freshw Res 49:447-453

* Park RA, O'Neill RV, Bloomfield JA (1974) A generalized model for simulating lake ecosystems. Simulation 23: 33-50

* Pauly D (1980) On the interrelationships between natural mortality, growth parameters, and mean environmental temperature in 175 fish stocks. ICES J Mar Sci 39:175-192

* Rico A, Satapornvanit K, Haque MM, Min J, Nguyen PT, Telfer TC, van den Brink PJ (2012) Use of chemicals and biological products in Asian aquaculture and their potential environmental risks: a critical review. Rev Aquacult 4:75-93

Scavia D, Bloomfield JA, Fisher JS, Nagy J, Park RA (1974) Documentation of CLEANX: a generalized model for simulating the open-water ecosystems of lakes. Simulation 23:51-56

* Shan K, Li L, Wang XX, Wu YL, Hu LL, Yu GL, Song LR (2014) Modelling ecosystem structure and trophic interactions in a typical cyanobacterial bloom-dominated shallow Lake Dianchi, China. Ecol Modell 291:82-95

Søndergaard M, Moss B (1998) Impact of submerged macrophytes on phytoplankton in shallow freshwater lakes. In: Jeppesen E, Søndergaard M, Søndergaard M, Christoffersen K (eds) The structuring role of submerged macrophytes in lakes. Springer, New York, NY, p 91-114

Tang JF (2013) Studies on fisheries ecology in a large Yunnan Plateau lake, Lake Erhai, China. PhD dissertation, Institute of Hydrobiology, Chinese Academy of Sciences, Wuhan (in Chinese with English Abstract)

Tong L (1999) Ecopath model—a mass-balance modeling for ecosystem estimation. Mar Fish Res 20:103-107 (in Chinese with English Abstract)

Tong L, Tang QS, Daniel P (2000) A preliminary approach on mass-balance Ecopath model of the Bohai Sea. Ying Yong Sheng Tai Xue Bao 11:435-440

Ulanowicz RE (1986) Growth and development: ecosystem phenomenology. Springer, Berlin

Ulanowicz RE, Puccia CJ (1990) Mixed trophic impacts in ecosystem. Coenoses 5:7-16

Wang Y, Bai T (2010) Research on resources status quo and protection measures of the Shangshe Lake wetland nature reserve in Wuhan City. J Hydroecol 3:135-137

Wang SM, Dou HS (1998) A directory of lakes in China. Science Press, Beijing (in Chinese)

*Wang L, Cai YL, Fang LY (2009) Pollution in Taihu Lake China: causal chain and policy options analyses. Front Earth Sci China 3:437-444

Wang QD, Liu JS, Li ZJ, Zhang TL (2015) Culture-based fisheries in lakes of the Yangtze River Basin, China, with special reference to stocking of mandarin fish and Chinese mitten crab. In: De Silva SS, Ingram BA, Wilkinson $\mathrm{S}$ (eds) Perspectives on culture-based fisheries developments in Asia. Scandmedia, Bangkok, p 99-110

Welcomme RL, Bartley DM (1998) Current approaches to the enhancement of fisheries. Fish Manag Ecol 5:351-382 
Wu XW, Rao JZ, He BW (1992) The history of the Chinese freshwater fisheries. In: Liu JK, He BW (eds) Cultivation of the Chinese freshwater fishes. Science Press, Beijing, p 5-29 (in Chinese)

Xie P (2003) Silver carp and bighead carp, and their use in the control of algal blooms. Science Press, Beijing (in Chinese)

Xie P, Liu JK (2001) Practical success of biomanipulation using filter-feeding fish to control cyanobacteria blooms: a synthesis of decades of research and application in a subtropical hypereutrophic lake. Sci World J 1:337-356

Yang GS, Ma RH, Zhang L, Jiang JH, Yao SC, Zhang M, Zeng HA (2010) Lake status, major problems and protection strategy in China. Hupo Kexue 22:85-92 (in Chinese with English Abstract)

Ye SW (2007) Studies on fish communities and trophic network model of shallow lakes along the middle reach of the Yangtze River. PhD dissertation, Institute of Hydrobiology, Chinese Academy of Sciences, Wuhan (in Chinese with English Abstract)

Yi CL, Guo LG, Ni LY, Luo CQ (2016) Silver carp exhibited an enhanced ability of biomanipulation to control cyanobacteria bloom compared to bighead carp in hyper-

Editorial responsibility: Catriona MacLeod,

Hobart, Tasmania, Australia eutrophic Lake Taihu mesocosms. Ecol Eng 89:7-13

Zeng YB (1995) Summary of technical progress in comprehensive fisheries exploitation of large and medium shallow weed-type lakes in China. Hupo Kexue 7:85-92 (in Chinese with English Abstract)

Zeng TH, Liu GX, Hu ZY (2011) Estimation of phytoplankton primary production of lakes in the middle and lower reaches of the Yangtze River. Resour Environ Yangtze Basin 20:717-722 (in Chinese with English Abstract)

Zhang TL (2005) Life-history strategies, trophic patterns and community structure in the fishes of Lake Biandantang. PhD dissertation, Institute of Hydrobiology, Chinese Academy of Sciences, Wuhan (in Chinese with English Abstract)

Zhang ZS, Mei ZP (1996) Effects of human activities on the ecological changes of lakes in China. GeoJournal 40: $17-24$

Z Zhang X, Xie P, Huang XP (2008) A review of nontraditional biomanipulation. Sci World J 8:1184-1196

Z Zhou B, Dong SL, Wang F (2015) Trophic structure and energy fluxes in a grass carp (Ctenopharyngodon idellus) cultured pond ecosystem. Aquacult Int 23:1313-1324

Submitted: July 31, 2017; Accepted: January 11, 2018

Proofs received from author(s): March 30, 2018 